\title{
Size and morphological features of native starch granules of different botanical origin
}

\section{Vladimir Litvyak}

\begin{abstract}
Scientific and Practical Centre for Foodstuffs of the National Academy of Sciences of Belarus, Minsk, Republic of Belarus
\end{abstract}

\section{Keywords:}

Starch

Morphology

Grain

Size

Shape

\section{Article history:}

Received

12.03.2018

Received in revised form 24.06.2018

Accepted

27.12.2018

\section{Corresponding} author:

Vladimir Litvyak

E-mail:

besserk1974@

mail.ru

DOI:

10.24263/2304-

974X-2018-7-4-3

\section{Abstract}

Introduction. When developing modern technologies for deep processing of plant starch-containing raw materials, the most important aspect is the study of the size and morphological structure of starch grains.

Materials and methods. Native potatoes, corn, tapioca, wheat, rice, rye, peas, amaranth, barley, sorghum, triticale and oats starches were studied. Scanning electron micrographs of starch grains were obtained using a scanning electron microscope LEO 1420. Metallization of native starch preparations was carried out with gold in the EMITECH $\mathrm{K} 550 \mathrm{X}$ vacuum system.

Results and discussion. The sizes and morphological features of the grains of native starch of different botanical origin were investigated. The main structural characteristic of the structure of native starch, which determines its physicochemical properties, is starch grain (granule). There was revealed a large variety of forms of starch grains: regular and irregular oval, rounded, multi-faceted. The size of starch grains varied within $60,0-0,5$ microns. Depending on the average size, starchy grains can be arranged in a descending row: potato $(21,7 \pm 1,22)$, rye $(21,2 \pm 2,36)$, pea $(20,4 \pm 2,57)$, chickpea $(14,8 \pm 0,93)$, triticale $(13,2 \pm 1,75)$, wheat $(12,4 \pm 1,90)$, sorghum $(11,0 \pm 0,76)$, barley $(10,9 \pm 1,15)$, tapioca $(10,6 \pm 0,50)$, corn $(9,8 \pm 0,42)$, oat $(7,39 \pm 0,87)$, rice $(5,3 \pm 0,29)$, amaranth $(1,1 \pm 0,04)$. The largest size of starch grains was found in potato starch, and the smallest size in amaranth starch. It was established that in 7 native starches (sorghum, barley, oat, pea, chickpea, amaranth and corn) the distribution of starch grains is monomodal in size (1-fractional), in 4 (wheat, triticale, potato and tapioca) - bimodal (2-fractional), in 2 (rye and rice) - trimodal (3fractional).

The source of starch-containing raw materials and the peculiarities of the structural organization of native starch largely determine the technological methods used for the most complete and gentle extraction of the seeds of native starch from the plant cell.

The main structural characteristic of the structure of native starch, which determines its properties, is starch grain. Features of the size and shape of starch grains cause the manifestation of the following properties of starch: molecular weight, the amount of bound moisture, temperature of gelatinization, the ratio of starch fractions and density of their laying in crystalline areas, the rheological characteristics of starch paste.

Conclusion. The morphology of starch grains of different botanical origin varies significantly in size $(60,0-0,5 \mu \mathrm{m})$ and shape (round, oval, irregular shape). The size of starch granules is the main structural characteristic determining the physicochemical properties of starch pastes. 


\section{Introduction}

The range of products of starch-treacle production is quite large and amounts to several hundred items [1-36]. The main raw material for the production of starch and starch products are potatoes $[6,34]$, corn $[19,35]$, wheat $[12,17]$, rye [2], barley $[13,22]$, rice $[4,21]$, buckwheat $[2,5]$, tapioca $[24,26]$, lentils [36], banana [31] etc. In addition to native starch, molasses of various carbohydrate compositions (low-sugared, caramel, high-sugared, maltose, dextrin-maltose) maltose, maltin, crystalline glucose, as well as glucose, glucosefructose and fructose syrups are produced [1]. A large range of modified starches and dextrins is available $[3,20]$.

Starch and starch products play an important role in the national economy [1-3]. They are widely used in many branches of food industry: confectionery, bakery, canning, food concentrates, dairy, meat, as well as in other industries: textile, paper, leather, printing, pharmaceutical, metallurgy, and household. In addition, starch and its derivatives are used in chemical industry in the production of sorbitol, lactic acid, glycerol, acetone, butanol, varnishes, various films, etc.

When developing modern technologies for deep processing of vegetable starchcontaining raw materials (technologies for obtaining native and modified starches), the most important aspect is the study of the size and morphological structure of starch granules.

Despite the great interest shown by the scientific community to fundamental and applied research in the field of starch and starch products, up to now there are no systematic studies of the morphological characteristics of starch granules (size and shape) isolated from plant materials of various botanical origin.

The aim is to study the size and morphological features of native starch granules of different botanical origin.

\section{Materials and methods}

\section{Materials}

The objects of the research are native starches: potato starch according to the Technical Normative Legal Act (TNPA), corn starch according to TNPA, tapioca starch according to TNPA, wheat starch according to TNPA, rice starch according to TNPA, rye starch according to TNPA, pea starch according to TNPA, amaranth starch according to TNPA, barley starch according to TNPA, sorghum starch according to TNPA, triticale starch according to TNPA, oat starch according to TNPA [37, 38].

\section{Methods}

\section{Scanning Electron Microscopy (SEM)}

Sample preparation. Metallization of native starch preparations was carried out with gold in the EMITECH K 550X vacuum unit.

Analysis. Scanning electron micrographs of native starch granules were obtained using a LEO 1420 scanning (raster) electron microscope (Germany) (Figure 1). 


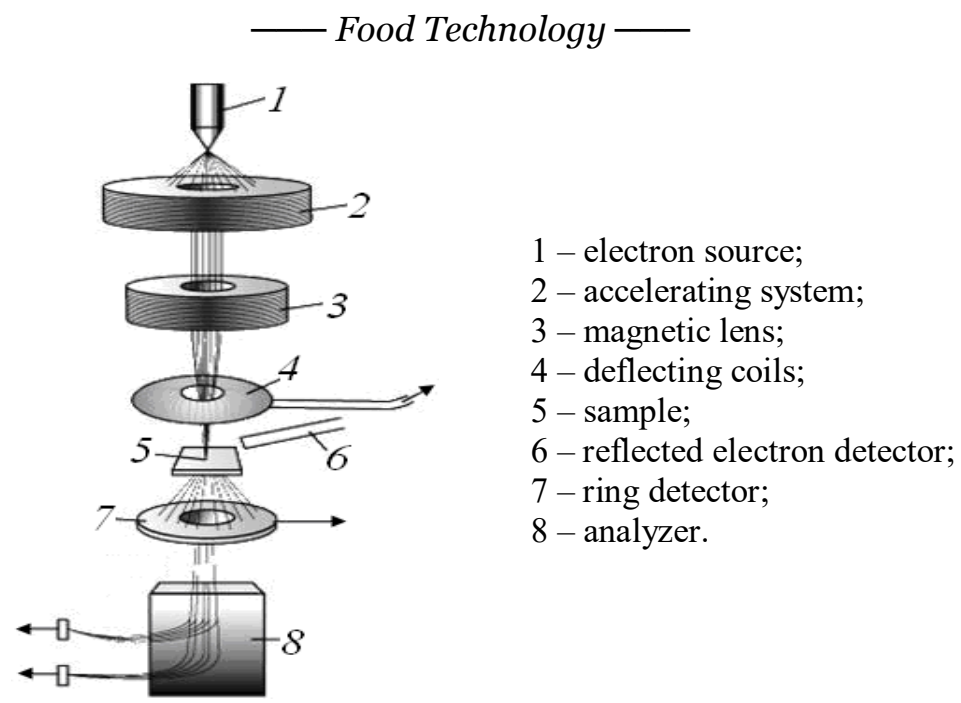

Figure 1. Scanning electron microscope

The principle of operation of the scanning electron microscope consists in scanning the sample surface with a focused electron beam and analyzing particles reflected from it and Xray radiation resulting from the interaction of electrons with matter. In a scanning electron microscope, an electron beam (electron probe) is focused by electromagnetic lenses of a capacitor and a lens $[39,40]$. A special device - deflector deflects the electron beam (primary electrons), which slides on the surface (raster). The secondary electrons (reflected from the surface) are perceived by the detector and are focused on the screen of the scanning electron microscope creating a three-dimensional image. The scanning electron microscope allows working in a wide range of magnifications from $\times 10$ (which is equivalent to an increase in a strong hand-held lens) to $\times 1000000$, which is $\approx 500$ times the increase limit of the best optical microscopes. The scanning surface is necessarily sprayed with metal: platinum, gold, silver, aluminum $[39,40]$.

\section{Statistical Analysis}

The dimensions of the starch granules were estimated using computer aids according to generally accepted procedures. Using MS Excel, the average values of starch granule size were calculated and the boundaries of the confidence interval were determined, and graphs of the distribution of starch granules by size [38] were plotted.

\section{Results and discussion}

\section{Results}

Granules of native starch, isolated from plant cells of various botanical origin, vary considerably in form and size, which largely determines the technological features of starch production, its further modification and subsequent use, if necessary $[2,9,15]$.

Scanning electron micrographs of native starch granules of various botanical origin: potato, corn, tapioca, wheat, rice, rye, pea, amaranth, barley, sorghum, triticale are shown in Figures 2-5. Figures 6 and 7 give the granulometric analysis of native starch granules of 
different botanical origin (the distribution of native starch granules by size). Granulometric analysis of native starch granules is based on the results given in Table 1. Table 1 shows the average, minimum and maximum granule sizes of native starches of different botanical origin with statistical processing characteristics of the sample studied.

The analysis of the morphological characteristics of native starch granules has shown that starchy granules predominantly have the following form: in rye and barley, oval and round, in wheat and triticale, regular oval and round, in pea and potato - irregular oval, in oat and tapioca - irregular round, in rice and corn - irregular polyhedral, in sorghum - oval and polyhedral, in chick pea - regular oval, in amaranth - polyhedral (Figure 2-5).

It has been established that the average granule size of native rye, wheat, triticale, sorghum, barley, rice, pea, chick pea, amaranth, tapioca, potato, corn, oat will accordingly be: $21,2( \pm 2,36) ; 12,4( \pm 1,90) ; 13,2( \pm 1,75) ; 11,0( \pm 0,76) ; 10,9( \pm 1,15) ; 5,3( \pm 0,29) ; 20,4$ $( \pm 2,57) ; 14,8( \pm 0,93) ; 1.1( \pm 0,04) ; 10,6( \pm 0,50) ; 21,7( \pm 1,22) ; 9,8( \pm 0,42) ; 7,39( \pm 0,87) \mu \mathrm{m}$ (Table 1). The minimum and maximum granule sizes of native rye, wheat, triticale, sorghum, barley, rice, pea, chick pea, amaranth, tapioca, potato, corn vary between: 4,9-42,8; 2,8-27,1; $4,0-30,7 ; 3,5-21,7 ; 3,0-21,4 ; 2,7-7,9 ; 6,1-32,3 ; 6,0-25,6 ; 0,5-1,5 ; 2,8-31,2 ; 7,7-60,0 ; 3,6-$ 19,2; 3,96-14,91 $\mu \mathrm{m}$ (Table 1).

According to the average size of the starch granules all the studied native starches can be arranged in a descending series $(\rightarrow$ ): potato $\rightarrow$ rye $\rightarrow$ pea $\rightarrow$ chick pea $\rightarrow$ triticale $\rightarrow$ wheat $\rightarrow$ sorghum $\rightarrow$ barley $\rightarrow$ tapioca $\rightarrow$ corn $\rightarrow$ oat $\rightarrow$ rice $\rightarrow$ amaranth. The largest size of starch granules was found in potato starch, and the smallest one - in amaranth starch.

In seven types of native starches (sorghum, barley, oat, pea, chick pea, amaranth and corn), the distribution of starch granules in size is mono modal (one fraction is clearly identified), in four types of native starches (wheat, triticale, potato and tapioca), distribution of starch granules in sizeis bimodal (two-fraction), and in two types of native starches (rye and rice), the distribution of starch granules in size is tri-modal (three-fraction) (Figures 6 and 7).

\section{Discussion}

Starch-containing raw materials for the production of native potato starch are tubers of the Solanum tuberosum (L.) potato plant [2,3], native corn (maize) starch - the Zea mays (L.) corn [21, 23], native tapioca starch - tubers of the Manihot utilissima (L.) and Manihot palmate (L.) plants $[2,26]$, native sorghum starch - the waxlike Red leoti (L.) sorghum plant [2], native wheat starch - grains of the Triticum genus plants [2,16], native triticale starch grains of the cereal triticale plant (Tritikale, from Latin «triticum» - wheat and from Latin «secale» - rye) - a hybrid of wheat and rye [2], and native rye starch - grains of the Secale cereale (L.) plants [2], native barley starch - grains of the Hordeum vulgare (L.) plant [2, 13], native oat starch - grains of the Avena sativa (L.) oat plant [2, 5], native rice starch grains of the Oryza sativa (L.) rice plants [2, 21], native pea starch - seeds of the Pisum sativum (L.) plants [2], native amaranth starch - the Joseph's-coat amaranth Amaranthus tricolor (L.) or other plants of the Amaranthus genus [2], native chick pea starch - the Cicer arietinum (L.) chick pea [2]. 

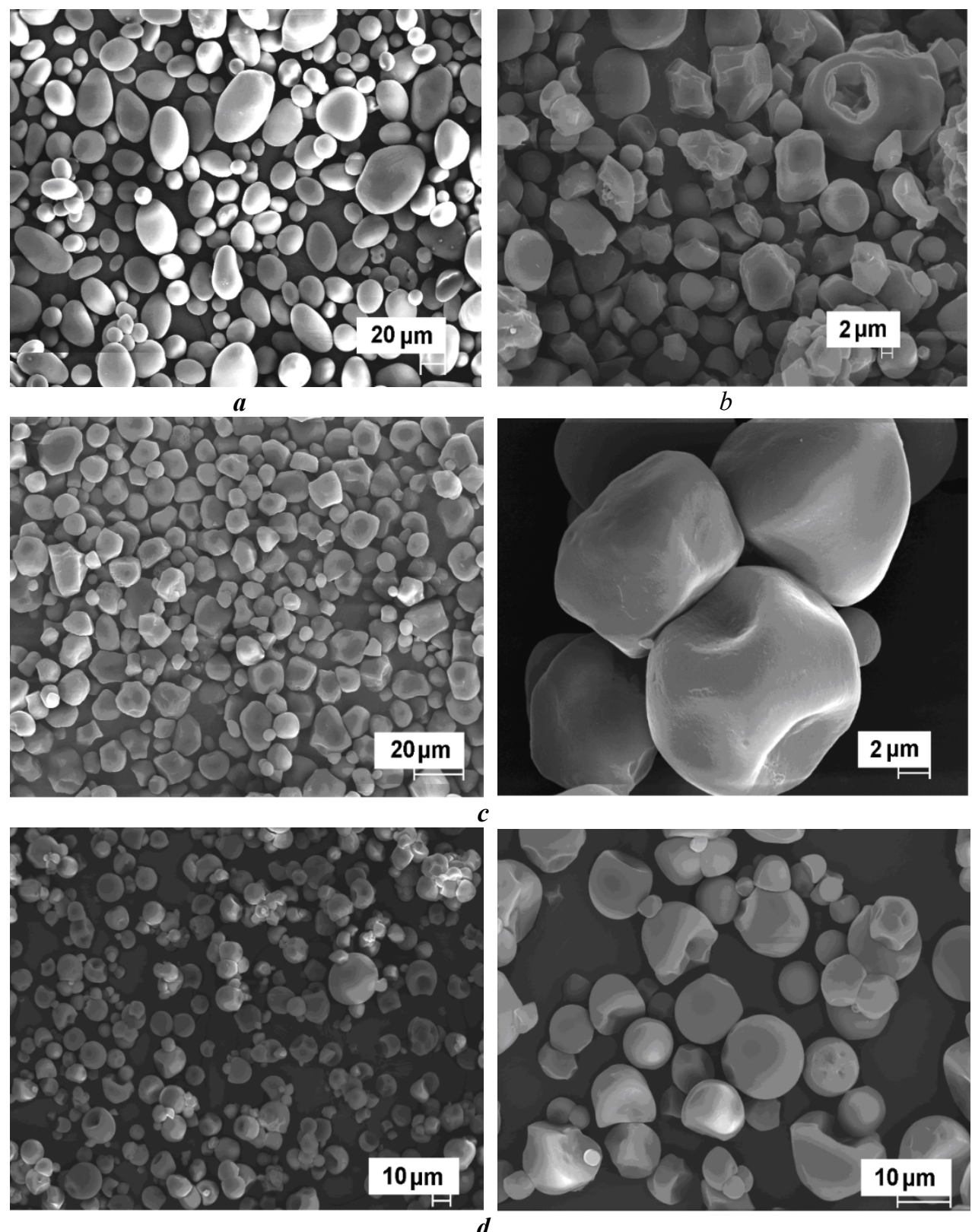

Figure 2. Scanning electron micrographs of native starch granules: $a$ - potato, $b$ - oats, $c$ - corn, $d$ - tapioca 

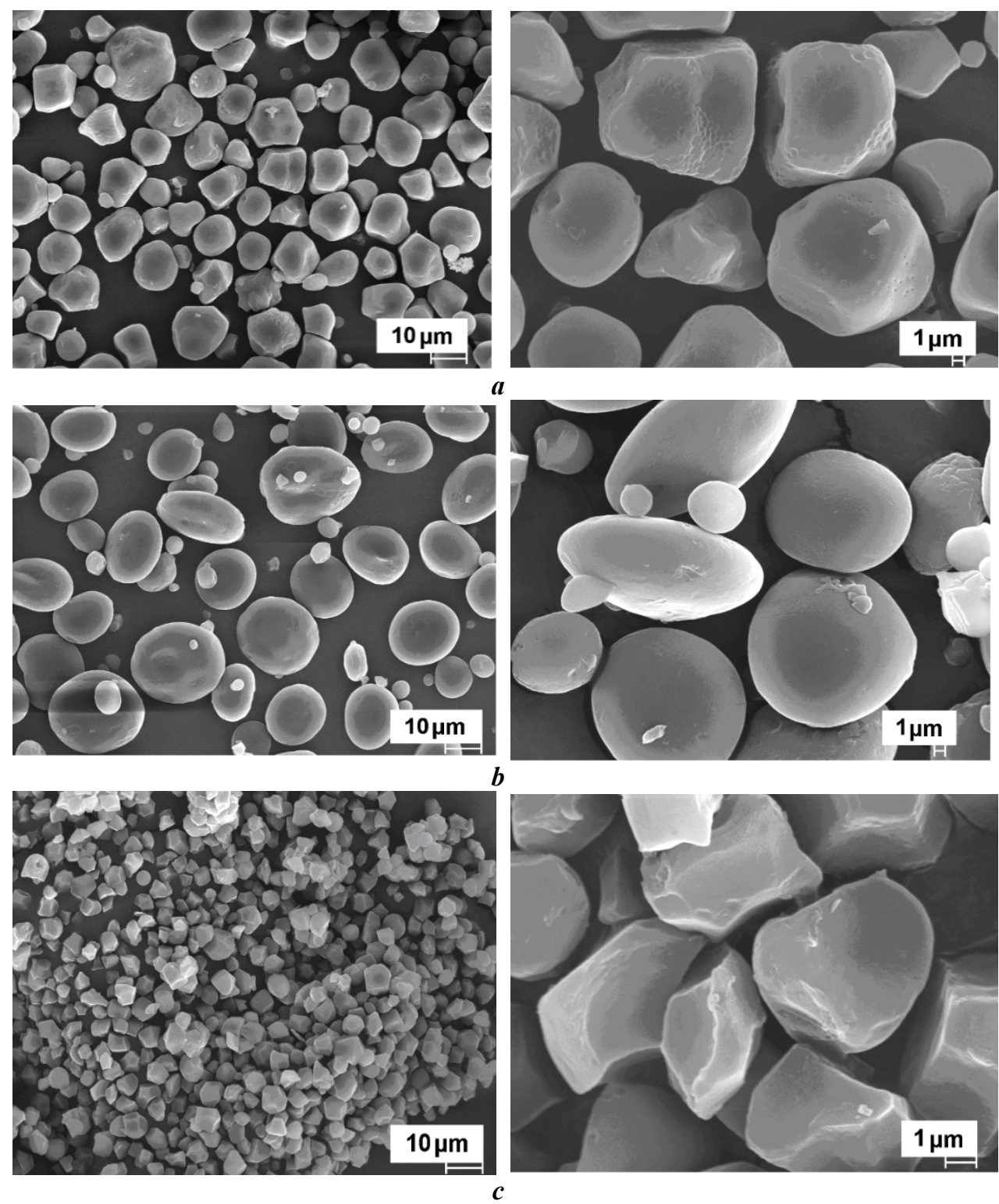

Figure 3. Scanning electron micrographs of native starch granule:

$a$ - sorghum, $b$ - wheat, $c$ - rice 


\section{- Food Technology}
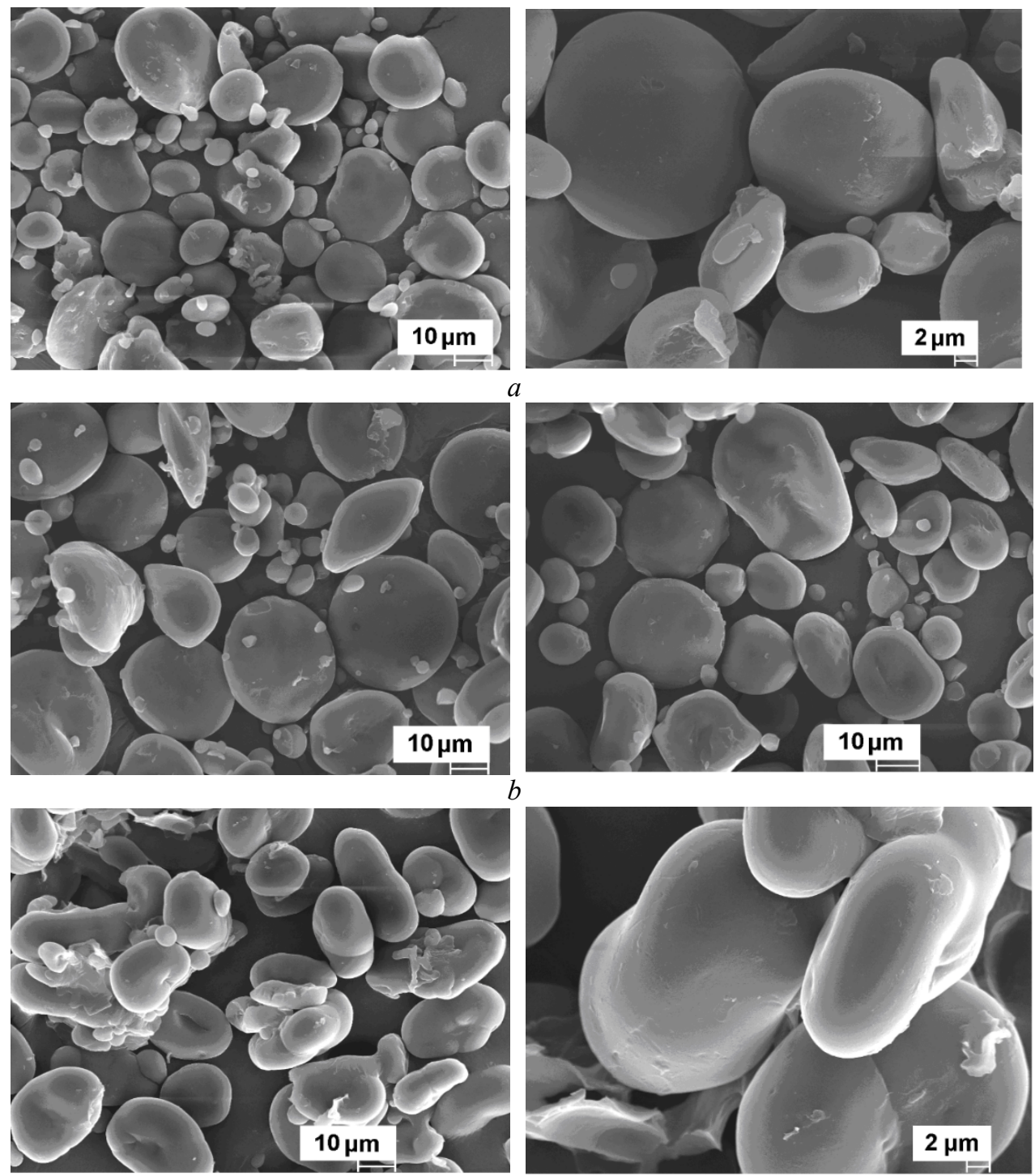

Figure 4. Scanning electron micrographs of native starch granules:

$a$ - triticale, $b$ - rye; $c$ - pea 

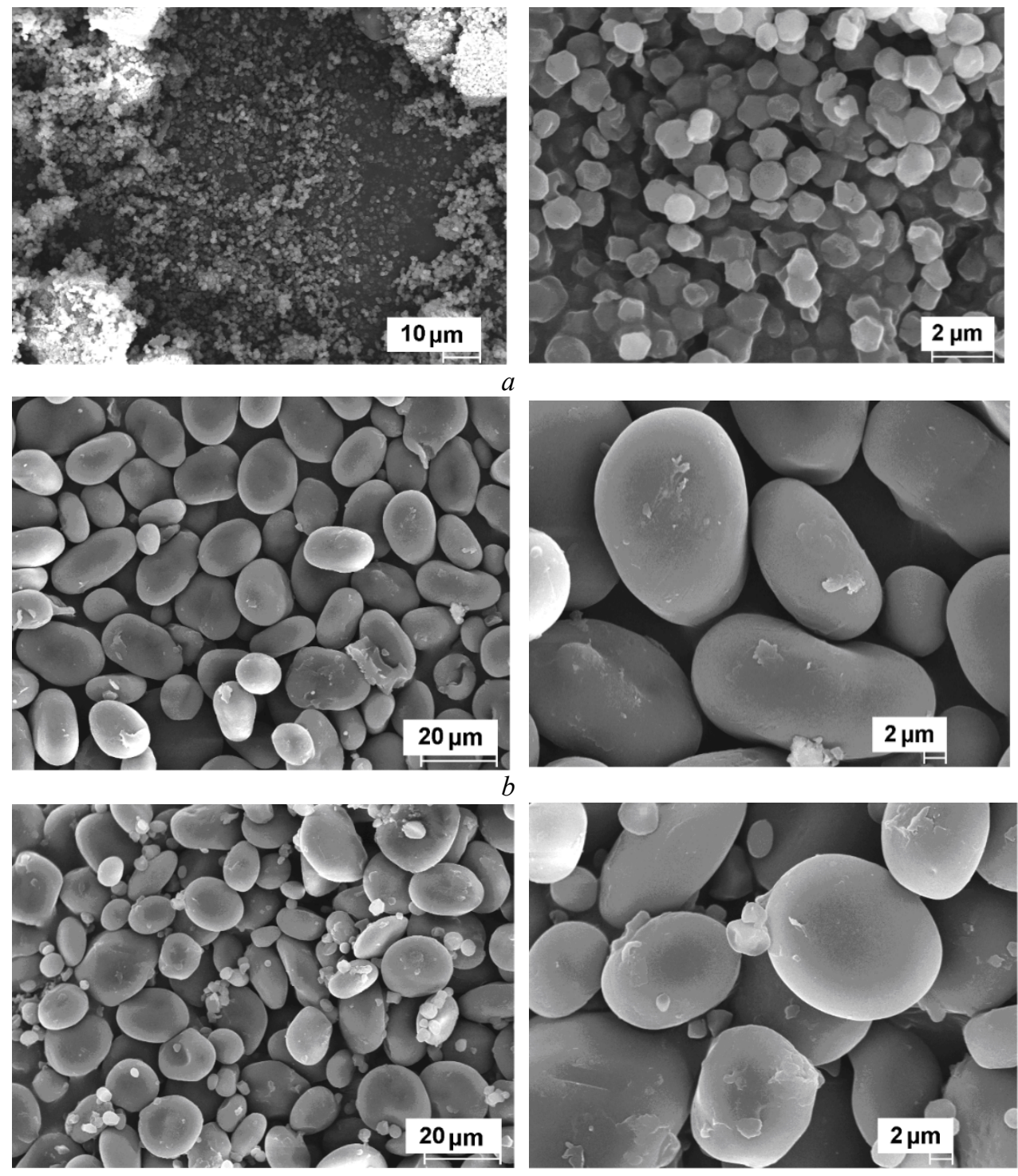

Figure 5. Scanning electron micrographs of native starch grains: $a$ - amaranth, $b$ - chick pea, $c$ - barley 


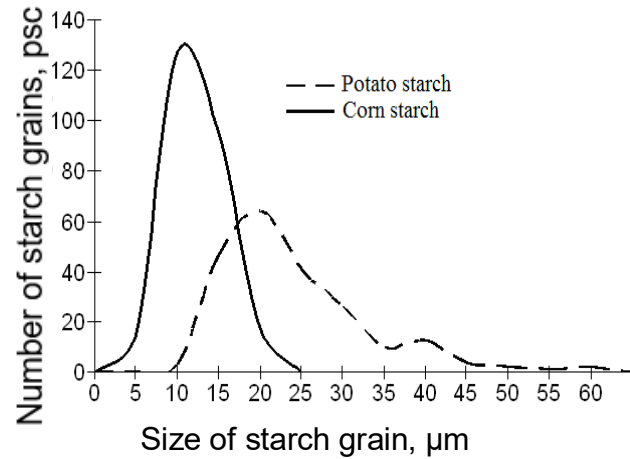

$a$

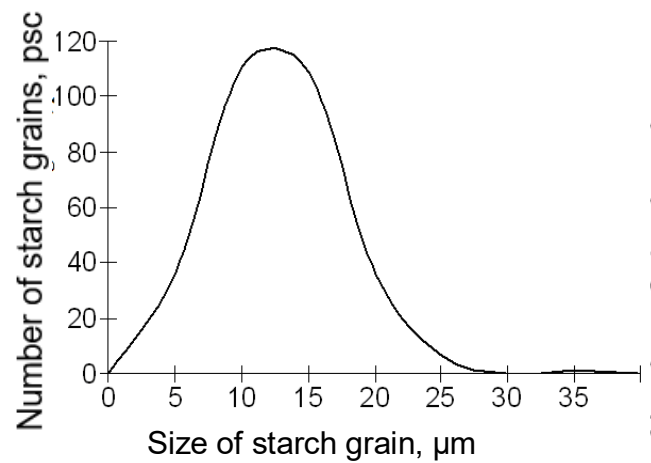

$\boldsymbol{c}$

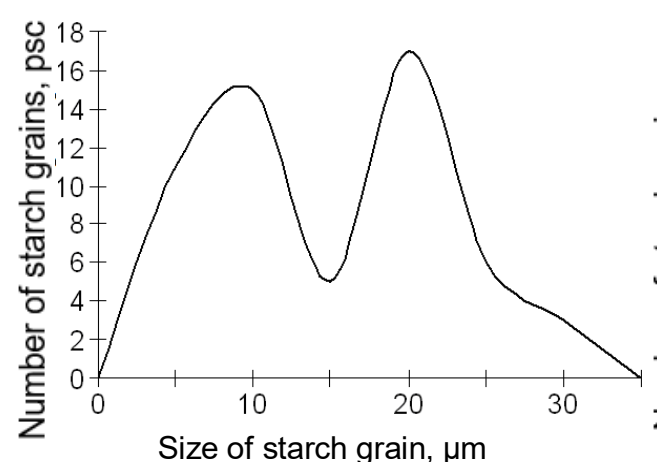

Size of starch grain, $\mu \mathrm{m}$

$\boldsymbol{e}$

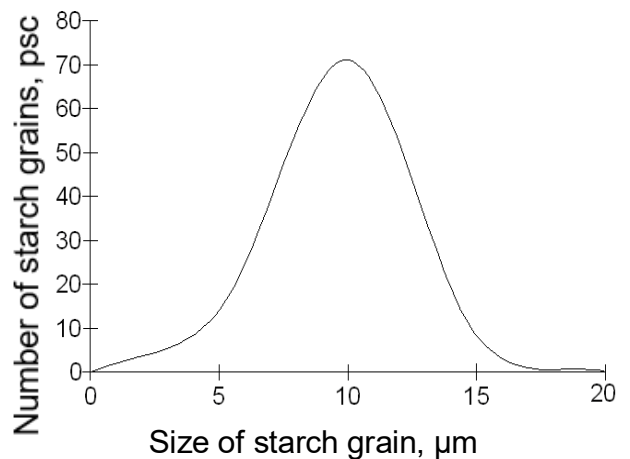

$\boldsymbol{b}$

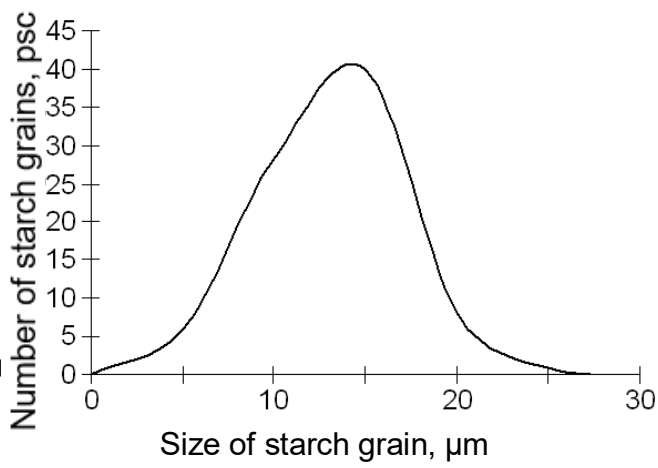

d

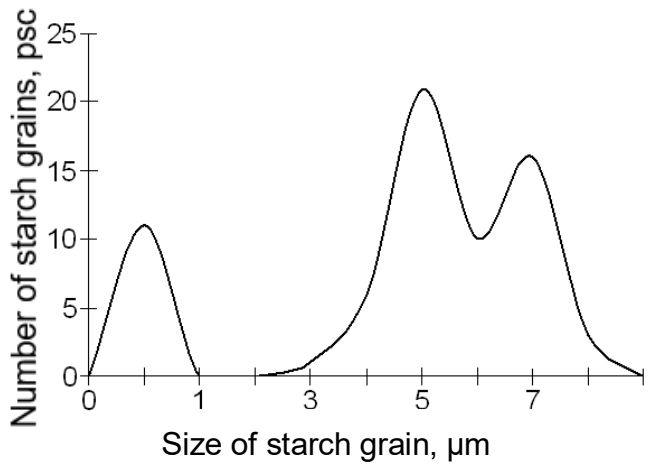

$f$

Figure 6 - Granulometric analysis of native starch grains:

$a$ - potato and corn, $\boldsymbol{c}$ - oat, $c$ - tapioca, $d$-sorghum, $e$ - wheat, $f$-rice 


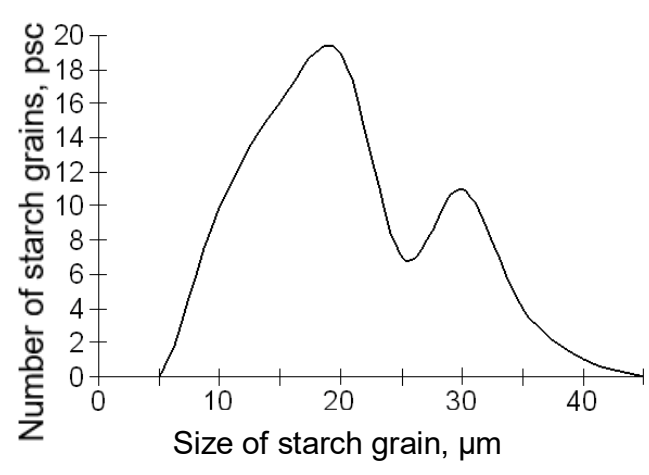

a

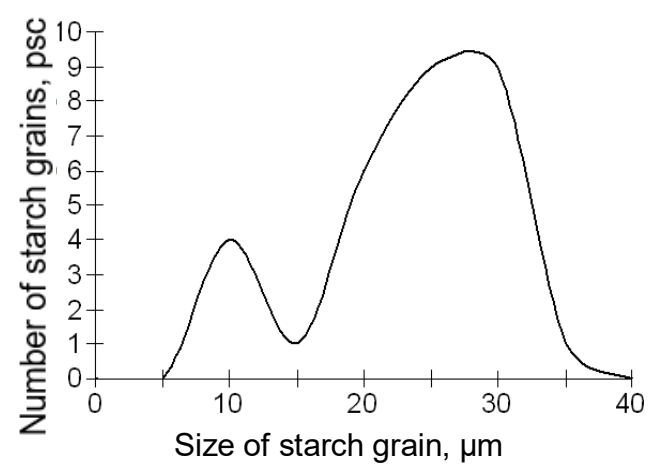

c

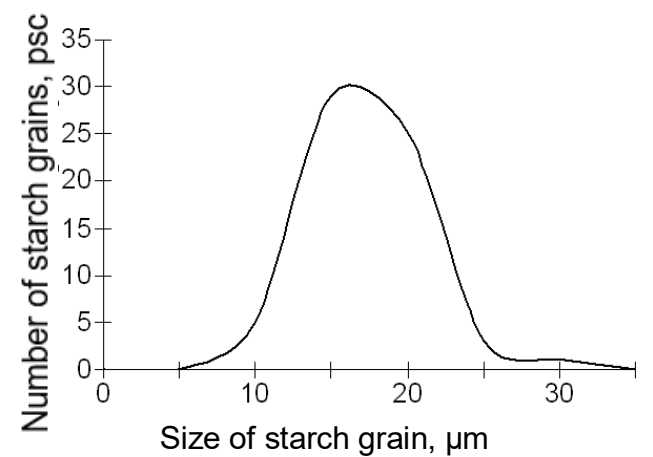

Size of starch grain, $\mu \mathrm{m}$

e

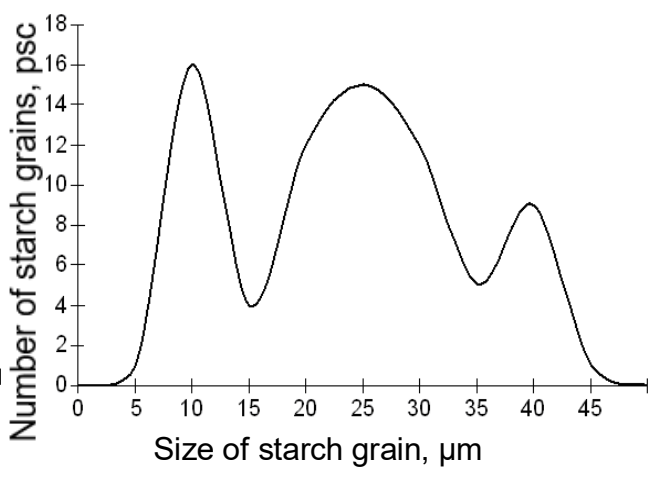

b

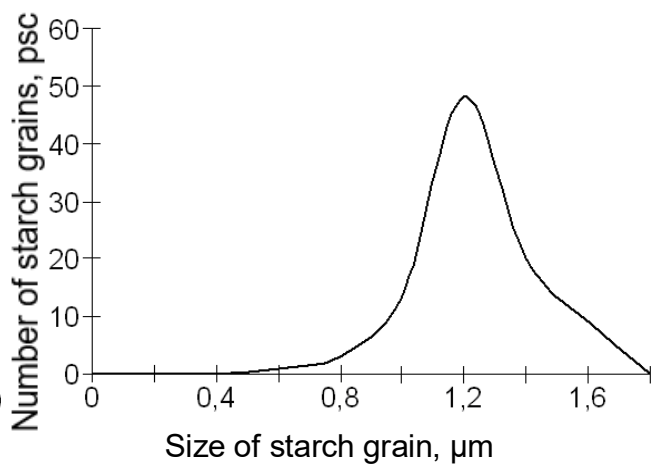

d

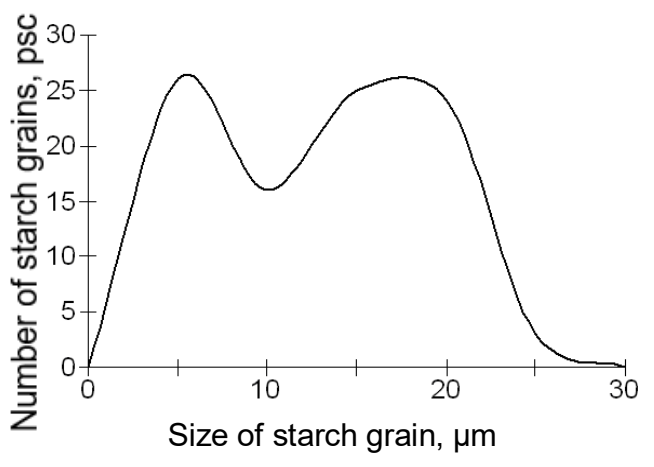

$f$

Figure 7. Granulometric analysis of native starch granules:

$a$ - triticale, $b$ - rye, $c$ - pea, $d$ - amaranth, $e$ - chick pea, $f$-barley 
Table 1

Morphological characteristic of native starches of different botanical origin

\begin{tabular}{|c|c|c|c|c|c|c|c|}
\hline \multirow{2}{*}{ Parameters } & \multicolumn{7}{|c|}{ Native starches } \\
\hline & 1 & 2 & \multicolumn{2}{|c|}{3} & 4 & 5 & 6 \\
\hline$d_{\text {aver. }}$ & 21,2 & 12,4 & \multicolumn{2}{|c|}{13,2} & 11,0 & 10,9 & 5,3 \\
\hline Standard error & 1,19 & 0,97 & \multicolumn{2}{|c|}{0,88} & 0,38 & 0,58 & 0,15 \\
\hline Median & 21,8 & 11,3 & \multicolumn{2}{|c|}{12,7} & 11,0 & 11,4 & 5,2 \\
\hline Mode & 22,4 & 2,8 & \multicolumn{2}{|c|}{13,1} & 12,2 & 4,5 & 4,1 \\
\hline Standard deviation & 10,27 & 7,31 & \multicolumn{2}{|c|}{7,24} & 3,49 & 5,63 & 1,11 \\
\hline Sample variance & 105,4 & 53,5 & \multicolumn{2}{|c|}{52,48} & 12,19 & 31,72 & 1,23 \\
\hline Excess & $-0,9$ & $-1,27$ & \multicolumn{2}{|c|}{$-0,67$} & 0,16 & $-1,34$ & $-0,59$ \\
\hline Asymmetry & 0,1 & 0,26 & \multicolumn{2}{|c|}{0,51} & 0,09 & 0,1 & 0,06 \\
\hline Interval & 37,9 & 24,3 & 26 & & 18,2 & 18,4 & 5,2 \\
\hline$d_{\min }$ & 4,9 & 2,8 & 4 & & 3,5 & 3,0 & 2,7 \\
\hline$d_{\max }$ & 42,8 & 27,1 & 30 & & 21,7 & 21,4 & 7,9 \\
\hline $\begin{array}{c}\text { Reliability level } \\
(95,0 \%)\end{array}$ & 2,36 & 1,90 & 1, & & 0,76 & 1,15 & 0,29 \\
\hline Upper limit & 23,5 & 14,3 & 1 & & 11,7 & 12,1 & 5,6 \\
\hline Lower limit & 18,8 & 10,5 & 11 & & 10,2 & 9,8 & 5 \\
\hline & & & & tive stal & rches & & \\
\hline Parameters & 7 & 8 & 9 & 10 & 11 & 12 & 13 \\
\hline$d_{\text {aver. }}$ & 20,4 & 14,8 & 1,1 & 10,6 & 21,7 & 9,8 & 7,39 \\
\hline Standard error & 1,25 & 2,46 & 0,02 & 0,26 & 0,62 & 0,21 & 0,43 \\
\hline Median & 20,8 & 14,5 & 1,1 & 10,1 & 19,0 & 9,7 & 6,57 \\
\hline Mode & н/д & 15,8 & 1,2 & 8,8 & 17,1 & 12,7 & 5,09 \\
\hline Standard deviation & 6,87 & 3,69 & 0,18 & 4,43 & 8,99 & 3,38 & 2,56 \\
\hline Sample variance & 47,22 & 13,59 & 0,03 & 19,63 & 80,88 & 11,44 & 6,57 \\
\hline Excess & 0,02 & 0,17 & 0,71 & 0,66 & 2,2 & $-0,49$ & 0,66 \\
\hline Asymmetry & $-0,74$ & 0,07 & $-0,32$ & 0,54 & 1,4 & 0,37 & 1,04 \\
\hline Interval & 26,3 & 19,6 & 1,0 & 28,4 & 52,3 & 15,5 & 10,96 \\
\hline$d_{\min }$ & 6,1 & 6,0 & 0,5 & 2,8 & 7,7 & 3,6 & 3,96 \\
\hline$d_{\max }$ & 32,3 & 25,6 & 1,5 & 31,2 & 60,0 & 19,2 & 14,91 \\
\hline $\begin{array}{c}\text { Reliability level } \\
(95 \%)\end{array}$ & 2,57 & 0,93 & 0,04 & 0,50 & 1,22 & 0,42 & 0,87 \\
\hline Upper limit & 23,0 & 15,7 & 1,2 & 11,1 & 22,9 & 10,2 & 8,25 \\
\hline Lower limit & 17,8 & 13,9 & 1,1 & 10,1 & 20,5 & 9,3 & 6,52 \\
\hline
\end{tabular}

Note: 1 - rye, $\mathbf{2}$ - wheat, $\mathbf{3}$ - triticale, $\mathbf{4}$ - sorghum, $\mathbf{5}$ - barley, $\mathbf{6}$ - rice, $\mathbf{7}$ - pea,

$\mathbf{8}$ - chick pea, 9 - amaranth, 10 - tapioca, 11 - potato, 12 - corn, 13 - oat

Native starch is a natural polymer in which monomers (the residues of $\alpha$-Dglucopyranose) are bound by $\alpha-(1 \rightarrow 4)$ - and $\alpha$ - $(1 \rightarrow 6)$-glucoside bonds to form amylose (a linear polysaccharide) and amylopectin (a branched polysaccharide structure). Starch fractions (amylose and amylopectin) are compactly packaged into starch grains (or granules) $[9,15]$.

The source of starch-containing raw materials and the peculiarities of the structural organization of native starch largely determine the technological methods used for maximally complete and gentle extraction of the granules of native starch from the plant cell. To obtain native starch it is necessary to prepare vegetable starch containing raw materials for processing, to destroy the plant cell, to extract the native starch, to wash it with pure water to 
remove the accompanying impurities, to dehydrate, to dry, to prepack and pack. It is known that there exist generally accepted methods of processing potatoes to obtain starch using a variety of technological schemes and various types of technological equipment. However, regardless of the equipment design, each of these methods includes the production stages that are characteristic of all modern technologies for the obtaining of potato starch: the preparation of potatoes for processing, grinding, the isolation of potato (cell) juice and pulp, the purification of starch, its dehydration and drying [2].

At present, the most rational method is the preparation of native potato starch, which involves preparation for processing and shredding of starch-containing raw materials, the use of a multistage hydro-cyclone unit which separates finely ground starch-based raw materials into a starch suspension and a mixture of pulp with other by-products. Subsequently, a partial thickening of the starch suspension is carried out, followed by dehydration, drying and removal of the metal-magnetic impurities, prepacking, packaging, labeling and transportation of the starch [2].

Methods of corn grain processing to obtain starch include five obligatory steps: preliminary softening of the corn grain structure by soaking it in an acid medium, isolating and washing the embryo, isolating and washing the pulp, isolating and concentrating the protein, washing the starch and drying it [2].

It is possible to improve the technology of native starch extraction in the most optimal way and also to abandon the technology of chemical modification in many respects. For that purpose it is necessary to apply the fundamental scientific principle that «the structure of a substance determines its properties» to the deep processing technologies for starchcontaining plant raw materials.

According to our results, as well as the data obtained by other researchers [42, 43], starch granules have an oval, spherical or irregular shape, their diameter varies from 0,001 to $0,2 \mathrm{~mm}$. Starchy granules are divided into simple and complex: simple granules are homogeneous formations; complex ones are a combination of smaller particles. The density of starch is an average of $1,5 \mathrm{~kg} / \mathrm{m}^{3}$.

The analysis of the peculiarities of the structure of native starch makes it possible to assume that the main structural characteristic of the native starch which determines its properties is starch grain (granule). Therefore the features of the size and shape of starch granules determine the manifestation of the following properties (characteristics) of starch:

1. The amount of bound moisture (the larger the starch granule is, the more bound moisture there is in starch and vice versa).

2. The temperature of gelatinization (the larger the starch granule is, the less its gelatinization temperature is and vice versa).

3. The ratio of starch fractions of the branched fraction of amylopectin and linear amylose (the formation of a starch granule is due to the interaction of linear sections of amylopectin with each other or with amylose).

4. Rheological characteristics of starch paste (viscosity of starch paste is due to the ratio of starch fractions of amylopectin and amylose).

\section{Conclusions}

1. The main structural characteristic of native starch, which determines its physicalchemical properties, is a starch granule.

2. A wide variety of forms of starch granules has been revealed. Starchy granules were found to be of a regular and irregular oval form, of a round form and a polyhedral one. 
3. The sizes of starch granules range within the following limits: $60,0-0,5$ microns. Depending on the average size of the starch granules the studied native starches can be arranged in a descending series: potato $(21,7 \pm 1,22)$, rye $(21,2 \pm 2,36)$, pea $(20,4 \pm 2,57)$, $(14,8 \pm 0,93)$, triticale $(13,2 \pm 1,75)$, wheat $(12,4 \pm 1,90)$, sorghum $(11,0 \pm 0,76)$, barley $(10,9 \pm 1,15)$, tapioca $(10,6 \pm 0,50)$, corn $(9,8 \pm 0,42)$, oat $(7,39 \pm 0,87)$, rice $(5,3 \pm 0,29)$, amaranth $(1,1 \pm 0,04)$. The largest size of starch granules was found in potato starch, and the smallest one - in amaranth starch.

4. It was found that in 7 native starches (sorghum, barley, oat, pea, chick pea, amaranth and corn) the distribution of starch granules in size is mono modal (1-fractional), in the four of them (wheat, triticale, potato and tapioca) - bimodal (2-fractional), in the two of them (rye and rice) - tri modal (3-fractional).

\section{References}

1. Gliuk N.G., Zhushman A.I., Ladur T.A., Shtyrkova E.A. (1985), Krakhmal i krakhmaloprodukty, Agropromizdat, Moscow.

2. Andreev N.R. (2001), Osnovy proizvodstva nativnykh krakhmalov, Pishchepromizdat, Moscow.

3. Zhushman A.I. (2007), Modifitsirovannye krakhmaly, Pishchepromizdat, Moscow.Nikhil K. Chrungoo, Ayam Gangarani Devi. (2015), Morphological and Rheological Properties of Starches Separated from Cultivars of Rice (Oryza sativa L.) from North East India, American Journal of Plant Sciences, 6, pp. 2019-2031.

4. Makella M.J., Laakso S. (2006), Studies on Oat Starch with a Celloscope: Granule Size and Distribution, Starch/Starke, 36, pp. 159-163.

5. Sylvia de Pater, Martien Caspers, Marijke Kottenhagen, Henk Meima, Renaldo Ter Stege, Nick de Vetten (2006), Manipulation of starch granule size distribution in potato tubers by modulation of plastid division, Plant Biotechnology Journal, 4, pp. 123-134.

6. Jane J-L., Kasemsuwan T., Leas S., Zobel H., Robyt J.F. (1994), Anthology of starch granule morphology by scanning electron microscopy, Starch/Starke, 46, pp. 121-129.

7. Malinski E.. Daniel J.R.. Zhang X.X.. Whistler R.L. (2003). Isolation of small starch granules and determination of their fat mimic characteristics, Cereal. Chem., 80, pp. 1-4.

8. Pérez S., Bertoft E. (2010). The molecular structures of starch components and their contribution to the architecture of starch granules: a comprehensive review, Starch/Starke, 62, pp. 389-420.

9. Buleon A.. Colonna P., Planchot V., Ball S. (1998), Starch granules: structure and biosynthesis, Int. J. Biol. Macromol., 23, pp. 85-112.

10. Sahlstrom S.. Brathen E.. Lea P.. Autio K. (1998). Influence of starch granule size distribution on bread characteristics, J. Cereal. Sci., 28, pp. 157-164.

11. Yonemoto P.G., Calori D.M.A., Franco C.M.L. (2007), Effect of granule size on the structural and physico- chemical characteristics of wheat starch, Ciênc. Tecnol. Aliment., 27, pp. 761-771.

12. Takeda Y., Takeda C., Mizukami H., Hanashiro I. (1999), Structures of large, medium and small starch granules of barlev grain. Carbohvd. Polvm. 38. pp. 109-114.

13. Swinkels J.J.M. (1985), Composition and Properties of commercial Native Starches, Starch/Starke, 37. - pp. $1-5$.

14. Zobel H.F. (1988), Molecules to Granules: A Comperehensive Starch Review, Starch/Starke, 40, pp. 44-50.

15. Dengate H., Meredith P. (1984), Variation in size distribution of starch granules from wheat grain, J. Cereal. Sci., 2, pp. 83-90.

16. Stoddard F.L. (1999). Survey of starch particle-size distribution in wheat and related species, Cereal. Chem., 76, pp. 145-9.

17. Lindebloom N, Chang P.R., Tyler R.T. (2004), Analytical, Biochemical and Hysiochemical Aspects of Starch Granule Size, with Emphasis on Small Granule Starches: A Review, Starch/Starke, 56, pp. 89-99.

18. Uarrota V.G., Amante E.R., Demiate I.M., Vieira F., Delgadillo I., Maraschin M. (2013), Physicochemical, thermal, and pasting properties of flours and starches of eight Brazilian maize landraces (Zea mays L.), Food Hydrocolloid, 30, pp. 614-624.

19. Neelam K., Viajay S., Lalit S. (2012), Various techniques for the modification of starch and the application of its derivatives, Int. Res. J. Pharm, 3, pp. 25-31. 
20. Hebeish A., El-Rafie M.H., El-Sisi F., Abdel Hafiz F., Abdel-Rahman A.A. (1994), Oxidation of maize and rice starches using potassium permanganate with various reductants, Polym. Degrad. Stab., 43, pp. 363-372.

21. Halal S.L.M., Colussi R., Pinto V.Z., Bartz J., Radunz M., Carreño N.L.V., Dias, A.R.G., Zavareze E.R. (2015), Structure, morphology and functionality of acetylated and oxidised barley starches, Food Chem., 168, pp. 247-256.

22. Ribeiro L.S., Cordoba L.P., Colman T.A., Oliveira C.S., Andrade M.M.P., Schnitzler E. (2014), Influence of some sugars on the thermal, rheological and morphological properties of "pinhão" starch, J.Therm. Anal. Calorim., 117, pp. 935-942.

23. Malucelli L.C., Lacerda L.G., Carvalho Filho M.A.S., Fernández D.E.R., Demiate I.M., Oliveira C.S., Schnitzler, E. (2015), Porous waxy maize starch, J. Therm. Anal. Calorim., 120, pp. 525-532.

24. Colman T.A.D., Demiate I.M., Schnitzler E. (2014), The effect of microwave radiation on some thermal, rheological and structural properties of cassava starch, J. Therm. Anal. Calorim., 115, pp. 2245-2252.

25. Beninca C., Colman T.A.D., Lacerda L.G., Carvalho-Filho M.A.S., Demiate I.M., Schnitzler E. (2013), Thermal, rheological, and structural behaviors of natural and modified cassava starch granules, with hypochlorite solutions, J. Therm. Anal. Calorim., 111, pp. 2217-2222.

26. Oliveira C.S., Andrade M.M.P., Colman T.A.D., Costa F.J.O.G., Schnitzler E. (2014), Thermal, structural and rheological behaviour of native and modified waxy corn starch with hydrochloric acid at different temperatures, J. Therm. Anal. Calorim, 115, pp. 13-18.

27. Beninca C., Demiate I.M., Lacerda L.G., Carvalho Filho M.A.S., Ionashiro M., Schnitzler E. (2008), Thermal behavior of corn starch granules modified by acid treatment at 30 and $50{ }^{\circ} \mathrm{C}$, Ecletica Quim., 33, pp. 13-18.

28. Liu X., Ma H., Yu L., Chen L., Tong Z., Chen P. (2014a), Thermal-oxidative degradation of highamylose corn starch, J. Therm. Anal. Calorim., 115, pp. 659-665.

29. Pietrzyk S., Fortuna T., Królikowska K., Rogozínska E., Labanowska M., Kurdziel M. (2013), Effect of mineral elements on physicochemical properties of oxidised starches and generation of free radicals, Carbohydr. Polym. 97, pp. 343-351.

30. Carmona-Garcia R., Sanchez-Rivera M.M., Mendez-Montealvo G., Garza-Montoya B., BelloPerez L.A. (2009), Effect of the cross-linked reagent type on some morphological, physicochemical and functional characteristics of banana starch (Musa paradisiaca), Carbohydr. Polym., 76, pp. $117-122$.

31. Liu J., Wang B., Lin L., Zhang J., Liu W., Xie J., Ding Y. (2014b), Functional, physicochemical properties and structure of cross-linked oxidized maize starch, Food Hydrocolloids, 36, pp. 45-52.

32. Kuakpetoon D., Wang Y.J. (2001), Characterization of different starches oxidized by hypochlorite, Starch/Starkë, 53, pp. 211-218.

33. Zhou F., Liu Q., Zhang H., Chen Q., Kong B. (2016), Potato starch oxidation induced by sodium hypochlorite and its effect on functional properties and digestibility, Int. J. Biol. Macromol., 84, pp. 410-417.

34. Spier F., Zavareze E.R., Silva R.M., Elias M.C., Dias A.R.G. (2013), Effect of alkali and oxidative treatments on the physicochemical, pasting, thermal and morphological properties of corn starch, J. Sci. Food Agric., 93, pp. 2331-2337.

35. Joshi M., Aldred P., McKinight S., Panozzo J.F., Kasapis S., Adhikari R., Adhukari, B. (2013), Physicochemical and functional characteristics of lentil starch, Carbohydr. Polym., 92, pp. 14841496.

36. Joint FAO/WHO Expert Committee on Food Additives (JECFA) (1992). Compendium of food additive specifications, vol. 1 and 2. FAO Food and Nutrition Paper 52/1, Food and Agriculture Organization of the United Nations, Rome.

37. National Academy of Sciences (1996), Food chemicals codex, 4th edn., National Academy Press, Washington.

38. McMullan D. (1988), Von Ardenne and the scanning electron microscope, Proc Roy Microsc Soc. 23. pp. 283-288.

39. Mignot, Christophe (2018), Color (and 3D) for Scanning Electron Microscopy, Microscopy Today, 26(3), pp. 12-17.

40. Rokitskii P.F. (1973), Biologicheskaia statistika, Minsk.

41. Litviak V.V., Ospankulova G.Kh., Shaimerdenova D.A., Iurkshtovich N.K., Butrim S.M., Rosliakov Iu.F. (2016), Atlas: morfologiia polisakharidov, EDIGE, Astana.

42. Litviak V.V., Rosliakov Iu.F., Butrim S.M., Kozlova L.N. (2013), Krakhmal i krakhmaloprodukty: monografiia, Krasnodar. 